\title{
PENERAPAN SANKSI TERHADAP PENGGUNA TELEPON GENGGAM SAAT BERKENDARA
}

\section{THE IMPLEMENTATION OF SANCTIONS AGAINST PHONE CELL USERS WHILE DRIVING}

\author{
D. NOVRIAN SYAHPUTRA \\ Fakultas Hukum Universitas Tulang Bawang \\ dnovrian89@gmail.com
}

\begin{abstract}
Abstrak
Fokus utama penelitian adalah penerapan sanksi pidana terhadap pengguna telepon genggam saat berkendaraan faktor-faktor penghambat dalam penerapan sanksi pidana terhadap pengguna telepon genggam saat berkendara. Metode pendekatan yang di gunakan dalam penelitian ini adalah normatif dan empiris dengan deskriptif-analitis. Hasil penelitian menunjukkan bahwa penerapan sanksi terhadap penggunaan telepon genggam saat berkendara oleh pengemudi kendaraan bermotor yaitu langsung diberikan surat bukti pelanggaran dan setelah itu dilanjutkan dengan proses persidangan di pengadilan kemudian membayar denda sesuai keputusan hakim. Faktor penghambat dalam penerapan sanksi pidana terhadap penggunaan telepon genggam saat berkendara terletak pada faktor masyarakat serta faktor budaya. Faktor masyarakat sangat mempengaruhi karena aturan hukum yang diterapkan tidak akan berjalan dengan baik jika sumber daya manusia atau masyarakatnya sendiri tidak menyadari akan pentingnya mematuhi aturan lalu lintas.
\end{abstract}

\section{Kata Kunci : Sanksi Pidana, Pengguna Telepon Genggam, Saat Berkendara}

\begin{abstract}
The main focus of the research is the application of criminal sanctions against phone cell users while driving. The inhibiting factors in the application of criminal sanctions against cell phone users while driving. The approach method used in this research is normative and empirical with descriptive-analytical. The results showed that the application of sanctions against the use of mobile phones while driving by motorized vehicle drivers was directly given a proof of violation and after that it was continued with a trial process in court and then paid a fine according to the judge's decision. The inhibiting factor in the application of criminal sanctions against the use of cell phones while driving lies in community factors and cultural factors. Community factors are very influencing because the applied legal rules will not run well if human resources or the community itself are not aware of the importance of obeying traffic rules.
\end{abstract}

Keywords : Criminal Sanctions, Phone Cell Users, While Driving 


\section{A. Pendahuluan}

Telepon genggam atau telepon seluler (selanjutnya disebut ponsel) adalah perangkat telekomunikasi elektronik yang mempunyai kemampuan dasar yang sama dengan telepon konvensional saluran tetap namun dapat dibawa kemana saja. Terdapat perbedaan antara telepon konvensional dengan ponsel, yaitu tidak terdapat fasilitas untuk mengakses sosial media pada telepon konvensional. Beberapa tahun belakangan ini jumlah pengguna ponsel terus menunjukkan peningkatan yang sangat signifikan. Hal itu disebabkan karena saat ini ponsel bukan termasuk barang mewah, tetapi ponsel saat ini telah menjadi suatu kebutuhan dalam melakukan komunikasi dengan kerabat, relasi dan lain sebagainya. Komunikasi tersebut dapat dilakukan di berbagai tempat misalnya, di rumah, di kantor, bahkan saat berkendara di jalan. Kendaraan merupakan suatu alat transportasi yang sangat dibutuhkan oleh masyarakat. Kendaraan dibagi menjadi dua macam, yaitu kendaraan umum dan kendaraan pribadi. Kendaraan umum merupakan kendaraan yang digunakan untuk angkutan masal baik untuk angkutan penumpang maupun barang, contohnya angkutan kota, bus, kereta api, kapal, dan pesawat. Kendaraan pribadi merupakan kendaraan yang digunakan sehari-hari untuk kepentingan pribadi, kendaraan pribadi itu dapat berupa mobil dan motor yang sering digunakan masyarakat untuk mencapai tempat tujuan.

Menggunakan kendaraan pribadi jauh lebih efisien dan lebih nyaman dibandingkan menggunakan kendaraan umum, sehingga kendaraan pribadi jumlahnya sangat dominan di jalan raya. Meningkatnya jumlah kendaraan pribadi dan kebutuhan akan kendaraan umum, maka meningkat pula masalah yang dihadapi. Salah satu masalah yang paling banyak terjadi yaitu semakin bertambahnya angka kecelakaan di jalan raya. Angka kecelakaan yang semakin tinggi disebabkan oleh kondisi infrastruktur jalan yang tidak baik, pengendara tidak mematuhi rambu - rambu lalu lintas, kerusakan yang tidak terdeteksi pada kendaraan, dan kurangnya konsentrasi pengguna jalan saat berkendara. Di Indonesia, aturan tentang larangan penggunaan ponsel saat berkendara telah diberlakukan. Penegak hukum akan memberikan sanksi bagi pengendara yang menggunakan ponsel 
saat mengendarai kendaraan. UndangUndang Nomor 22 Tahun 2009 tentang Lalu Lintas dan Angkutan Jalan, menyebutkan bahwa setiap orang yang mengemudikan kendaraan bermotor di jalan wajib mengemudikan kendaraannya dengan wajar dan penuh konsentrasi. Penjelasan umum Peraturan Perundangundangan Nomor 22 Tahun 2009 menerangkan bahwa lalu lintas dan angkutan jalan adalah satu kesatuan sistem yang terdiri atas Lalu Lintas, Angkutan Jalan, Jaringan Lalu Lintas dan Angkutan Jalan, Prasarana Lalu Lintas dan Angkutan Jalan, Kendaraan, Pengemudi, Pengguna Jalan, serta pengelolaannya.

Semakin padat arus lalu-lintas suatu jalan, maka faktor kehati-hatian dari pengguna jalan juga harus ditingkatkan seperti yang tercantum dalam Pasal 106 ayat (1) Undang-undang Nomor 22 Tahun 2009 tentang Lalu-Lintas Dan Angkutan Jalan, bahwa setiap orang yang mengemudikan kendaraan bermotor di jalan wajib mengemudikan kendaraannya dengan wajar dan penuh konsentrasi.

Pasal ini juga diperjelas dalam Undang- undang yang sama yaitu pada Pasal 283 bahwa setiap orang yang mengemudikan Kendaraan Bermotor di jalan secara tidak wajar dan melakukan kegiatan lain atau dipengaruhi oleh suatu keadaan yang mengakibatkan gangguan konsentrasi dalam mengemudi di jalan sebagaimana dimaksud dalam Pasal 106 ayat (1) dipidana dengan pidana kurungan paling lama 3 (tiga) bulan atau denda paling banyak Rp750.000,00 (tujuh ratus lima puluh ribu rupiah). Kedua pasal ini menegaskan bahwa setiap pengendara kendaraan bermotor selayaknya berkonsentrasi penuh dalam mengendara dan tidak diperkenankan untuk melakukan hal lain selain mengemudi. Pada saat sekarang ini, keberadaan kedua pasal ini dikaitkan dengan maraknya penggunaan telepon genggam ketika berkendara di jalan raya. Konsenterasi juga menjadi hal yang utama ketika seseorang mengendarai kendaraan, dan sudah jelas ketika seorang pengendara menggunakan telepon ketika berkendara di jalan raya, konsentrasi itu akan berkurang bahkan hilang. Peneliti pun memiliki pengalaman tersendiri melihat teman memakai telepon dengan menyelipkan telepon diantara helm dengan telinga untuk melakukan pembicaraan dengan temannya. Tindakan semacam ini seakan-akan menjadi hal yang biasa dan umum di masyarakat sekarang ini, mereka tidak mengganggap ini menjadi hal yang yang harus dikhawatirkan. 
Secara garis besar kecelakaan lalulintas cenderung disebabkan oleh 4 faktor yang saling berkaitan, yakni:

1. Manusia;

2. Kendaraan;

3. Jalan raya;

4. Lingkungan; ${ }^{1}$

Aturan memang tertulis jelas bahwa diperlukan konsentrasi penuh ketika berkendara, Pasal 106 ayat (1) UndangUndang Nomor 22 Tahun 2009 tentang Lalu Lintas dan Angkutan Jalan dan dalam penjelasan pasal ini menerangkan bahwa salah satu aktivitas yang membuat kehilangan konsentrasi adalah menggunakan telepon, tetapi terdapat beberapa hal yang sulit untuk dilakukan, apakah yang salah aturan hukum yang dibuat dan diberlakukan ataukah dari perilaku serta kesadaran masyarakat yang belum memahami dan mampu melakukan aturan tersebut, inilah yang menjadi fenomena di dalam masyarakat yang menjadi masalah sosial yang sangat rumit dan kompleks sehingga membutuhkan solusi yang tepat dalam hal penanggulangannya. mengendarai kendaraannya dia harus benar-benar fokus

\footnotetext{
${ }^{1}$ Pusat Penelitian dan Pengembangan, Fakultas Hukum Universitas Tarumanegara, Inventarisasi dan Analisa Terhadap Perundang-undangan Lalu- lintas, Jakarta: CV. Rajawali, 1984, hlm.77
}

dan berkonsenterasi pada jalan, sehingga perjalanan menjadi aman dan tentram.

\section{B. Metode Penelitian}

Metode yang dipergunakan dalam penelitian yakni yuridis normatif. Metode ini dilakukan dengan cara menelusuri dan menelaah berbagai peraturan perundangundangan, teori-teori dan konsep-konsep yang berhubungan dengan permasalahan. ${ }^{2}$

Bahan hukum yang digunakan adalah bahan primer dan bahan hukum sekunder.. Teknik pengumpulan data yaitu studi kepustakaan. Bahan hukum dianalisis secara kualitatif yaitu mengungkapkan dan menguraikan data yang diperoleh dalam bentuk kalimat perkalimat yang disusun secara terperinci, logis dan sistematis mengenai pokok bahasan sehingga dapat ditarik suatu kesimpulan. Setelah semua data selesai diolah secara kualitatif, kemudian dianalisa sesuai dengan pokok bahasan yaitu menganalisa tentang penerapan sanksi terhadap penggunaan telepon genggam saat berkendaraan berdasarkan Undang- Undang Nomor 22 Tahun 2009 tentang Lalu Lintas dan Angkutan Jalan.

\footnotetext{
${ }^{2}$ Soerjono Soekanto, Pengantar Penelitian Hukum, Jakarta: Universitas Indonesia UIPress,2002, hlm 6.
} 


\section{Pembahasan}

\section{Penerapan Sanksi Pidana Terhadap Pengguna Telepon Genggam Saat \\ Berkendara}

Berkembangnya teknologi telepon genggam sebagai telepon jaringan bergerak telah memiliki fungsi-fungsi lain dengan berbagai fitur, sehingga tidak hanya difungsikan sebagai alat komunikasi, melainkan telah menjadi telepon pintar. Namun, manfaat dari telepon genggam tersebut dibatasi oleh aturan perundang-undangan, yang salah satunya adalah Undang-Undang Nomor 22 Tahun 2009 tentang Lalu Lintas dan Angkutan Jalan Pasal 106 Ayat (1) yaitu : "setiap orang yang mengemudikan kendaraan bermotor di jalan wajib mengemudikan kendaraannya dengan wajar dan penuh konsentrasi". Norma tersebut melarang penggunaan telepon genggam oleh setiap orang yang sedang mengemudikan kendaraan bermotor. Ketentuan tersebut kemudian didukung oleh Pasal 283 Undang-Undang Nomor 22 Tahun 2009 tentang Lalu Lintas dan Angkuta Jalan bahwa :

"Setiap orang yang mengemudikan Kendaraan Bermotor di jalan secara tidak wajar dan melakukan kegiatan lain atau dipengarluhi oleh suatu keadaan yang mengakibatkan gangguan konsentrasi dalam mengemudi di jalan sebagaimana dimaksud dalam pasal 106 ayat (1) dipidana dengan pidana kurungan paling lama 3 (tiga) bulan atau denda paling banyak Rp. 750.000,00 (tujuh ratus lima puluh ribu rupiah) yang mengatur sanksi pidana bagi siapapun yang melanggar aturan dalam Pasal 106 Undang-Undang Nomor 22 Tahun 2009 tentang Lalu Lintas dan Angkuta Jalan.”

Pelanggaran lalu lintas merupakan pelanggaran terhadap persyaratan administrasi dan/atau pelanggaran terhadap persyaratan teknis oleh pemakai kendaraan bermotor sesuai ketentuan Peraturan Perundang-undangan lalu lintas yang berlaku. Pelanggaran merupakan suatu tindakan yang tidak sesuai dengan aturan yang ada, baik dalam norma masyarakat atau hukum yang berlaku. Dalam konteks ini pelanggaran lalu lintas adalah suatu tindakan baik sengaja ataupun tidak sengaja melakukan perbuatan untuk tidak mematuhi aturanaturan lalu lintas yang ditekankan pada tujuannya, yakni untuk mencegah agar orang tidak melakukan kejahatan, maka bukan bertujuan untuk pemuasan absolut atas keadilan. $^{3}$

Istilah dan makna pidana tidak dapat dipisahkan dengan hukum berlaku. Hukum Pidana dan Pemidanaa merupakan dua hal yang berkaitan. Pemidanaan terkait dengan

\footnotetext{
${ }^{3}$ Zainal Abidin Farid, Hukum Pidana 1, Jakarta: Sinar Grafika, 2007, hlm.11
} 
penghukuman, istilah tersebut berasal dari kata "hukum", sehingga dapat diartikan sebagai menetapkan hukum atau memutuskan tentang hukumannya. Oleh karena itu istilah tersebut harus disempitkan artinya, yaitu penghukuman dalam perkara pidana yang seringkali disinonimkan dengan pemidanaan atau pemberian atau penjatuhan pidana oleh hakim. Hukum pidana materiil dan hukum pidana formil dijadikan acuan dalam membahas masalah perkembangan sistem pemidanaan dan sistem sanksi.

Hukum pidana materil merupakan suatu kumpulan aturan hukum yang menentukan pelanggaran pidana, menetapkan syarat- syarat bagi pelanggar pidana untuk dapat dihukum, menunjukkan orang dapat dihukum dan dapat menetapkan hukuman atas pelanggaran pidana. Hukum pidana formil adalah kumpulan aturan hukum yang mengatur cara mempertahankan hukum pidana materil terhadap pelanggaran yang dilakukan orang-orang tertentu, atau dengan kata lain mengatur cara bagaimana hukum pidana materil diwujudkan sehingga memperoleh keputusan hakim serta mengatur cara melaksanakan putusan hakim. Jadi hukum pidana materil berisi larangan atau perintah dan jika tidak terpenuhi akan diancam sanksi, sedangkan hukum pidana formil adalah aturan hukum yang mengatur cara menjalankan dan melaksanakan hukum pidana materil.

Pemidanaan bukan sebagai pembalasan atas kesalahan pelaku tetapi sarana mencapai tujuan yang bermanfaat untuk melindungi masyarakat menuju kesejahteraan masyarakat. Pidana dan perbuatan-perbuatan yang diancam pidana harus lebih dahulu tercantum dalam undang undang. Hal ini sesuai dengan asas yang disebut dengan nullum delictum nulla poena sine praevia lege poenali, seperti yang tercantum dalam Pasal 1 Ayat (1) KUHP menyatakan :

"suatu perbuatan tidak dapat dipidana, kecuali berdasarkan kekuatan ketentuan perundangundangan pidana yang telah ada."

Dalam hal ini terdapat perbedaan istilah hukuman dan pidana. Suatu pidana harus berdasarkan undang-undang, sedangkan hukuman lebih luas pengertiannya, karena dalam pengertian hukuman, di dalamnya termasuk keseluruhan norma, baik norma kepatutan, kesopanan, kesusilaan dan kebiasaan.

Faktor penyebab pelanggaran lalu lintas oleh pengendara disebabkan oleh manusia itu sendiri karena kurangnya kesadaran akan peraturan berlalu lintas dan kepentingan-kepentingan manusia yang berlainan menyebabkan manusia ceroboh, lalai, bahkan kesengajaan menjadi faktor 
dominan terjadinya pelanggaran lalu lintas, seperti tidak membawa helm, melawan rambu lalu lintas, menerobos lampu lalu lintas, melewati batas marka jalan, dan melewati batas beban aman kendaraan (motor dinaiki oleh 3 orang), menggunakan telepon genggam saat berkendaraan. Keadaan di atas membuktikan kualitas kesadaran hukum masyarakat (pemakai jalan) belum memenuhi himbauan disiplin nasional.

Kesadaran hukum pada hakekatnya adalah bicara tentang kesadaran atau nilainilai yang terdapat di dalam diri manusia tentang hukum yang ada atau tentang hukum yang diharapkan. Hal ini sesuai dengan yang dinyatakan oleh Soerjono Soekanto bahwa "kesadaran hukum merupakan suatu penilaian terhadap hukum yang ada atau yang diharapkan”. Selanjutnya dinyatakan bahwa "pada umumnya manusia akan taat pada hukum dan penegaknya atas dasar imitasi, sugesti, identifikasi dan simpati baik secara terpisah maupun secara akumulatif'. Hukum merupakan salah satu faktor yang mempengaruhi kesadaran hukum masyarakat. Dalam ilmu hukum terdapat adigium bahwa setiap orang dianggap tahu hukum pada saat hukum dinyatakan berlaku, sehingga secara logika hukum tersebut dapat diterapkan setelah aturan tersebut dinyatakan berlaku. Hukum dibuat untuk dilaksanakan, hukum tidak lagi disebut hukum manakala tidak dilaksanakan dalam masyarakat.

Kepolisian sebagai salah satu lembaga yang mempunyai tanggung jawab dalam melakukan penegakan hukum dan menjadi ujung tombak dalam menanggulangi terjadinya tindak pidana, dimana polisi merupakan penyidik utama dalam menangani suatu tindak pidana. Sebagai institusi pertama yang berinteraksi langsung dengan tindak pidana, maka diperlukan suatu keahlian dan kecakapan khusus dalam menghadapi tindak pidana yang terjadi di masyarakat. Polisi memberikan pelayanan kepada masyarakat guna memberikan perlindungan dan rasa aman bagi masyarakat.

Undang-Undang Nomor 22 Tahun 2009 tentang Lalu Lintas dan Angkutan Jalan terdapat banyak pasal-pasal yang menjelaskan tentang lalu lintas dan angkutan jalan serta tujuan dari undangundang tersebut, salah satu nya dalam pasal 4 yaitu "Undang-Undang ini berlaku untuk membina dan menyelenggarakan Lalu Lintas dan Angkutan Jalan yang aman, selamat, tertib, dan lancar."

Undang-Undang Nomor 22 Tahun 2009 tentang Lalu Lintas dan Angkutan Jalan, dalam hal berlalu lintas wajib dipatuhi bagi setiap pengguna jalan dalam 
berkendara dikarenakan hal ini

Tahun 2009 tentang Lalu menyangkut keselamatan orang banyak antara lain :

a. Untuk pengendara sepeda motor menggunakan helm standar nasional Indonesia. (terdapat pada Pasal 57 Ayat 2 dan Pasal 106 Ayat 8 Undang- Undang Nomor 22 Tahun 2009 tentang Lalu Lintas dan Angkutan Jalan)

b. Kelengkapan berkendara harus lengkap sekurang-kurangnya sabuk keselamatan, ban cadangan, segitiga pengaman, dongkrak, pembuka roda, helm, dan rompi pemantul cahaya bagi pengemudi kendaraan bermotor roda empat/lebih yang tak memiliki rumah- rumah dan perlengkapan P3K. (Pasal 57 Ayat 3 UndangUndang Nomor 22 Tahun 2009 tentang Lalu Lintas dan Angkutan Jalan)

c. Setiap orang yang mengemudikan kendaraan bermotor di jalan secara tidak wajar dan melakukan kegiatan lain atau dipengaruhi oleh suatu keadaan yang mengakibatkan gangguan konsentrasi dalam mengemudi, dipidana dengan pidana kurungan paling lama tiga bulan kurungan atau denda paling banyak Rp 750.000. (Pasal 283 jo Pasal 106 ayat (1) Undang-Undang Nomor 22

d. Para pengendara, baik roda dua maupun roda empat atau lebih, harus mengutamakan keselamatan pejalan kaki dan pesepeda. Bagi mereka yang tidak mengindahkan aturan ini, akan dipidana dengan pidana kurungan paling lama dua bulan atau denda paling banyak Rp 500.000. (Pasal 106 Ayat 2 Undang-Undang Nomor 22 Tahun 2009 tentang Lalu Lintas dan Angkutan Jalan)

e. Bagi pengemudi sepeda motor diwajibkan memenuhi persyaratan teknis dan lain jalan yang meliputi kaca spion, klakson, lampu utama, lampu rem, lampu penunjuk arah, alat pemantul cahaya, alat pengukur kecepatan, knalpot, dan ke dalaman alur ban. Sanksi bagi pelanggarnya dipidana dengan pidana kurungan paling lama satu bulan atau denda paling banyak Rp 250.000. (Pasal 285 ayat 1 jo Pasal 106 ayat 3 UndangUndang Nomor 22 Tahun 2009 tentang Lalu Lintas dan Angkutan Jalan) dan lain sebagainya.

Larangan menggunakan telepon genggam saat berkendara tersebut di atur dalam Pasal 106 Ayat 1 UndangUndang Nomor 22 Tahun 2009 tentang Lalu Lintas dan Angkutan Jalan yakni 
pada saat berkendara, pengendara wajib "penuh konsentrasi" maksudnya penuh perhatian dan tidak terganggu karena sakit, lelah, mengantuk, menggunakan telepon atau menonton televisi atau video yang terpasang di Kendaraan, atau meminum minuman yang mengandung alkohol atau obat-obatan sehingga memengaruhi kemampuan dalam mengemudikan Kendaraan. Pasal tersebut dengan jelas menuliskan bahwa penggunaan telepon genggam dilarang karena akan mengganggu konsentrasi dan bagi pelanggarnya akan di kenakan sanksi pidana dengan pidana kurungan paling lama 3 (tiga) bulan atau denda paling banyak Rp750.000,00 (tujuh ratus lima puluh ribu rupiah) seperti yang tercantum dalam Pasal 283 Undang- Undang Nomor 22 Tahun 2009 tentang Lalu Lintas dan Angkutan Jalan. Aturan hukum serta sanksi dalam berkendara seperti ini sangat di Perlukannya sosialisasi hukum agar masyarakat, khususnya pengemudi mengetahui dengan jelas dan rinci bagaimanakah aturannya, seperti apakah aturannya, serta bagaimana dan seperti apa bentuk sanksinya, agar semua masyarakat, dan pengemudi memahami isi dan sanksi dari Pasal 106 Ayat (1) Undang-Undang Nomor 22 Tahun 2009 tentang Lalu Lintas dan Angkutan Jalan.
Sosialisasi bahaya penggunaan telepon genggam saat berkendara memang sudah dilaksanakan oleh pihak kepolisian, sosialisasi ini telah dilakukan secara langsung kepada pengemudi serta banyak juga di sosialisasikan melalui media sosial seperti facebook, instagram, dan lain-lain. Sosialisasi yang dilakukan oleh pihak kepolisian sudah maksimal. Sosialisasi juga sudah dilakukan oleh pihak kepolisian pada saat pengemudi membuat surat izin mengemudi (SIM), bukan hanya bahayanya saja yang di sosialisasikan namun sanksi pidananya pun sudah sering disosialisasikan. Sosialisasi bertujuan untuk menyadarkan masyarakat, serta pengemudi kendaraan bagaimana berkendara dengan baik serta bertujuan untuk mengurangi resiko-resiko terjadinya kecelakaan lalu lintas karena kurangnya pengetahuan serta pemahaman terhadap Undang-Undang Nomor 22 Tahun 2009 tentang Lalu Lintas dan Angkutan Jalan. Sosialisasi ataupun upaya-upaya kepolisian agar masyarakat, serta pengemudi kendaraan bermotor memahami undang-undang ini sudah dilakukan secara maksimal, tetapi memang masih banyak sekali masyarakat, serta pengemudi kendaraan bermotor yang masih melanggar aturan 
tersebut sehingga pihak memberikan sanksi sesuai Undang- Undang Nomor 22 Tahun 2009 Pasal 283 yakni pidana kurungan paling lama 3 (tiga) bulan atau denda paling banyak Rp 750.000,00 (tujuh ratus lima puluh ribu rupiah). Pihak kepolisian akan memberikan sanksi yang langsung akan diberikan oleh khususnya Satlantas yang bertugas di sepanjang jalan Bandar Lampung adalah melakukan tilang terhadap para pengemudi berupa sanksi bukti pelanggaran (tilang) oleh pihak satlantas yang sedang bertugas. Proses tersebut sudah berlangsung dan akan terus dilaksanakan oleh pihak kepolisian khususnya pihak kepolisian satuan lalu lintas (satlantas) yang bertugas mengatur jalannya lalu lintas agar tertib dan aman.

\section{Faktor Penghambat Dalam}

Penerapan Sanksi Pidana Terhadap Pengguna Telepon Genggam Saat Berkendara

Pelanggaran lalu lintas adalah perbuatan yang bertentangan dengan lalu lintas dan atau peraturan pelaksanaannya, baik yang dapat menimbulkan kerugian jiwa ataupun yang tidak dapat menimbulkan kerugian jiwa atau benda dan juga keamanan, ketertiban, dan kelancaran berlalulintas (kamtibcarlantas). Dengan adanya suatu peraturan tersebut diatas dan apabila masyarakatnya turut serta menerapkan aturan tersebut dalam berkendara, kemungkinan besar bisa menekan jumlah kecelakaan yang bahkan sering terjadi dijalan raya. Banyak kecerobohan yang mengakibatkan kurang berhati-hatinya seseorang yang kerap menimbulkan kecelakaan dan dengan kecerobohan tersebut memberikan dampak kerugian bagi orang lain. Menurut Pasal 310 Undang-Undang Nomor 22 Tahun 2009 tentang Lalu Lintas dan Angkutan Jalan bahwa apabila kealpaan atau kelalaian pengemudi itu mengakibatkan orang lain terluka atau meninggal dunia ancaman pidananya sebagaimana yang diatur dalam Pasal tersebut. Meski Undang-Undang Nomor 22 Tahun 2009 tentang Lalu Lintas dan Angkutan Jalan telah diterapkan sampai dengan sekarang tapi tidak dapat dipungkiri bahwa tingkat kecelakaan masih tetap terjadi. Dengan banyaknya kasus kecelakaan di jalan raya setidaknya hal itu bias menggambarkan cerminan masyarakatnya betapa minimnya kesadaran hukum bagi pengendara, karena masih banyak orang-orang dalam mengemudikan kendaraannya tidak tertib dan taat pada rambu-rambu lalu lintas.

Maraknya pelanggaran lalu lintas yang mengakibatkan korban luka-luka bahkan menelan korban jiwa 
(meninggal) nampaknya tidak membuat pelanggar hukum lalu lintas jera, bahkan beberapa peristiwa pelanggaran lalu lintas yang mengakibatkan korban meninggal disebabkan oleh kealpaan manusia pengguna lalu lintas, dampaknya sangat besar. Ada kesan bahwa penegak hukumnya tidak mampu mengantisipasi maraknya pelanggarann lalu lintas dengan korban meninggal dunia. Menangani pelanggaran lalu lintas aparat kepolisian satuan lalu lintas (satlantas) memberikan sanksi bagi pengemudi yang melangar aturan lalu lintas yang telah diatur dalam Undang-undang Nomor 22 tahun 2009 tentang Lalu Lintas dan Angkutan Jalan. Sebagai aparat penegak hukum tentunya posisi mempunyai fungsi dan tugas- tugas sebagai pelayan dan pelindung masyarakat. Selain tugas dan fungsi tersebut polisi juga sebagai aparat yang harus mempertahankan aturanaturan hukum yang tertulis dengan melakukan tindakan-tindakan hukum apabila ada yang melanggar aturan hukum tersebut. Persoalan mempertahankan aturan-aturan hukum tersebut dalam hal ini adalah persoalan yang sering muncul dalam kehidupan sehari-hari yaitu aturan dalam berkendara di lalu lintas yang diatur dalam Undang- Undang Nomor 22 Tahun 2009 tentang Lalu Lintas dan Angkutan Jalan.
Transportasi dan lalu lintas memiliki peranan yang sangat penting dalam terwujudnya salah satu ketertiban kehidupan masyarakat, karena berhubungan dengan kehidupan atau aktivitas setiap harinya. Pada praktiknya banyak sekali pengemudi baik roda dua maupun roda empat yang masih tidak taat terhadap aturan-aturan dalam berkendara seperti tidak mematuhi rambu lalu lintas, tidak memakai helm, serta penggunaan telepon genggam saat berkendara yang saat ini sangat banyak pengemudi khususnya pengemudi transportasi online yang melakukan hal ini karena tuntutan pekerjaan. Persoalan tersebut menjadi perhatian aparat kepolisian karena dalam operasional kerja seorang pengemudi transportasi online tersebut menggunakan telepon genggam, hal ini bukan saja melanggar aturan hukum yang berlaku tetapi juga akan mengancamkan keselamat pengemudi tersebut dan orang lain, karena hal itu dapat mengganggu konsentrasi dalam mengemudikan kendaraannya baik roda dua maupun roda empat.

Kendala dalam penerapan sanksi terhadap pengemudi kendaraan bermotor ini dapat dikaitkan dengan faktor-faktor yang mempengaruhi penegakan hukum yaitu anatara lain : 
1. Faktor Hukum nya itu sendiri Perlu disosialisasikan kembali agar hukum atau norma yang mengatur pelanggaran tersebut dapat teredukasi kepada masyarakat luas.

2. Faktor Penegak Hukum

Penegak hukum dalam hal ini adalah aparat kepolisian sudah melakukan sebuah upaya berupa sosialisasi dan pemberian surat bukti pelanggaran (tilang), namun sepertinya upaya yang dilakukan belum efektif karena terkadang aparat kepolisian tidak melakukan sanksi secara merata karena masih ada pengemudi kendaraan bermotor yang menggunakan telepon genggam saat berkendara tetapi tidak diberikan surat bukti pelanggaran (tilang).

3. Faktor sarana dan prasana

Sarana dan prasarana sebagai salah satu faktor yang mempengaruhi penegakan hukum terhadap pelanggaran lalu lintas antara lain mencakup peralatan yang memadai, dan sebagainya. Tanpa adanya sarana dan prasarana yang memadai, sangat menunjang bagi penegak hukum dalam menjalankan peranan secara maksimal.Sarana dan prasarana yang dimaksud sepertinya kamera cctv yang dapat memantau setiap pelanggaran dan dapat merekam setiap kejadian sebagai alat bantu yang menunjang dalam penegakan hukum bagi aparat kepolisian dalam menerapkan sanksi pidana terhadap pelanggaran lalu lintas yang di atur dalam Undang-Undang Nomor 22 Tahun 2009 tentang Lalu Lintas dan Angkutan Jalan.

4. Faktor masyarakat

Masyarakat merupakan salah satu elemen yang mempengaruhi penegakan hukum, oleh karena itu untuk mewujudkan penegakan hukum yang baik harus melibatkan masyarakat, karena warga masyarakat sebagai salah satu faktor yang mempengaruhi penegakan hukum, karena efektifitas penegakan hukum sangat tergantung pada kepatuhan hukum masyarakat. Sebab, bagaimanapun baiknya peraturan hukum dan bagusnya kualitas petugas serta lengkapnya fasilitas, jika warga masyarakat yang terkena ruang lingkup peraturan tersebut tidak memiliki kesadaran untuk mematuhi peraturan tersebut. Kurangnya kesadaran hukum di dalam masyarakat serta ketidakpatuhan masyarakat mengenai peraturan lalu lintas, hal ini yang dapat menghambat dalam penerapan sanksi tersebut. 
5. Faktor Budaya

Dalam hal ini kultur hukum merupakan gambaran dari sikap dan perilaku terhadap hukum, serta keseluruhan faktor-faktor yang menentukan bagaimana sistem hukum memperoleh tempat yang sesuai dan dapat diterima oleh warga masyarakat dalam kerangka budaya masyarakat. Semakin tinggi tingkat kesadaran hukum masyarakat maka akan tercipta budaya hukum yang baik dan dapat merubah pola pikir masyarakat selama ini. Budaya atau kebisaan masyarakat dalam penggunaan telepon genggam setiap hari bahkan setiap menitnya ini juga dapat mepengaruhi dalam penggunaan telepon genggam saat berkendara misalnya dalam penggunaan aplikasi yang terdapat di dalam telepon genggam seperti Google map dan lainnya.

Berdasarkan uraian diatas dapat menganalisis bahwa yang menjadi kendala utama dalam menerapkan sanksi tersebut adalah masalah dari masyarakat dan budaya masyarakat dalam beraktifitas sehari-hari. Kesadaran masyarakat akan bahaya penggunaan telepon genggam saat berkendara yang akan merugikan diri sendiri serta orang lain itulah yang menjadi kendala utama karena sosialisasi dan peringatan sudah sangat banyak dilakukan oleh aparat kepolisian dari berbagai media, termasuk media sosial seperti instagram, facebook, youtube, siaran di radio serta mensosialisasikan nya langsung kepada pihak terkait. Pentingnya kesadaran akan aturan hukum ini sangat mempengaruhi karena jika seorang pengemudi kendaraan bermotor menyadari akan guna dari mentaati aturan hukum saat berkendara maka para pengemudi kendaraan bermotor tidak akan membahayakan diri sendiri juga pengemudi lainnya

\section{Kesimpulan}

Berdasarkan hasil penelitian dan pembahasan dapat disimpulkan bahwa penerapan sanksi terhadap penggunaan telepon genggam saat berkendara oleh pengendara kendaraan bermotor yang termasuk pelanggaran diatur dalam Undang-Undang Nomor 22 Tahun 2009 tentang lalu Lintas dan Angkutan Jalan yaitu langsung diberikan surat bukti pelanggaran (tilang) dan setelah itu dilanjutkan dengan proses persidangan di pengadilan lalu membayar denda sesuai dengan yang ditentukan oleh pihak pengadilan dan disesuaikan dengan Pasal 283 Undang- Undang Nomor 22 Tahun 2009 tentang lalu Lintas dan Angkutan 
Jalan, sanksi pidana dengan pidana kurungan paling lama 3 (tiga) bulan atau

\section{Daftar Pustaka}

denda paling banyak Rp 750.000.

Penerapan sanksi ini sudah berlaku dan akan terus dijalankan oleh aparat kepolisian khususnya kepolisian satuan lalu lintas (satlantas) yang bertugas menjaga keamanan dan ketertiban di jalan raya karena pelanggaran ini akan menimbulkan kecelakaan yang akan membahayakan diri sendiri dan orang lain.

Faktor penghambat dalam penerapan sanksi pidana terhadap penggunaan telepon genggam saat berkendara oleh pengemudi saat berkendaraan ini terletak pada faktor masyarakat serta faktor budaya. Dimana faktor masyarakat sangat mempengaruhi karena aturan hukum yang diterapkan tidak akan berjalan dengan baik jika sumber daya manusia atau masyarakatnya sendiri tidak menyadari akan pentingnya mematuhi aturan lalu lintas yang dijelaskan di dalam UndangUndang Nomor 22 Tahun 2009 tentang Lalu Lintas dan Angkutan Jalan demi ketertiban dan keamanan serta keselamatan masyarakat dalam melakukan aktifitas sehari-hari, serta faktor budaya dimana seluruh masyarakat dari semua kalangan yang menggunakan telepon genggam tidak mengenal tempat dan waktu.

\section{Buku}

Farid, A.Z.Abidin dan A.Hamzah. 2006. Hukum Pidana I. Jakarta : PT Raja Grafindo Persada.

Pusat Penelitian dan Pengembangan. 1984. Fakultas Hukum Universitas Tarumanegara, Inventarisasi dan Analisa

Soekanto, Soerjono, 2002. Pengantar. Penelitian Hukum. Jakarta : UI. Press.

\section{Peraturan Perundang - Undangan}

Undang-Undang Dasar Republik Indonesia Tahun 1945 Undang-Undang Nomor 22 Tahun 2009 tentang Lalu Lintas dan Angkutan Jalan 